\title{
Advocacy for Counseling and Counselors: A Professional Imperative
}

\author{
Jane E. Myers, Thomas J. Sweeney, and Victoria E. White
}

\begin{abstract}
Although advocacy both for clients and for the profession is essential for the future of counseling and counselors, advocacy for the profession has received little systematic attention. A national plan for advocacy is needed, the effectiveness of which depends on achieving consensus concerning professional identity, promoting a positive public image, establishing effective intraprofessional and interprofessional collaboration, and obtaining the participation of each counselor in advocacy activities. Specific professional advocacy skills and techniques are described.
\end{abstract}

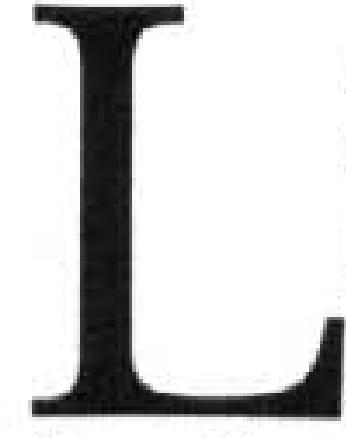

ee (1998) defined advocacy as "the process or act of arguing or pleading for a cause or proposal" (p. 8). Within this context, he recommended that counselors become agents of social change, intervening not just in the lives of their clients but in the world around them as well. Advocacy for clients and advocacy for the counseling profession receive equal emphasis in that counselors may plead the cause of others, may argue for the advancement of the counseling profession, and may, in both instances, find themselves intervening with systems and organizations as well as individuals and families.

Unfortunately, advocacy for clients' and advocacy for the counseling profession are frequently viewed as opposite and incompatible activities. For example, McClure and Russo (1996) suggested that the counseling profession has moved away from its activist roots and become less socially engaged, processes viewed as undesirable. They noted that the struggle for public acceptance of the profession and an increased emphasis on accreditation and credentialing are factors that contribute to the inability of professional counselors to be effective advocates for social change. An alternate position exists, one in which the two processes of advocacy are not juxtaposed but are seen as complementary and intertwined. From this perspective, the establishment of a legitimate position for professional counselors among the mental health professions is viewed as necessary for counselors to be perceived as credible and, in turn, would empower them to become effective advocates for clients and agents of social change (Chi Sigma lota, 1999).
A review of the literature in counseling, including searches of electronic databases (e.g., ERIC/CASS, PsycINFO), the American Counseling Association library, and books and journals in the field, revealed few resources on advocacy for the profession. Most of the advocacy literature focuses on strategies for addressing the needs of clients through social activism (e.g., McWhirter, 1997), with attention to special populations such as oppressed groups (Lewis \& Arnold, 1998). Literature on client advocacy has existed in various forms for more than two decades. For example, counselors in schools have been encouraged to include advocacy as part of a comprehensive program to help minority students (Perry \& Locke, 1985). Rehabilitation counselors have been urged to consider advocacy as an ethical imperative (Vash, 1987). In addition, teaching self-advocacy skills to clients is viewed as an important role for counselors (White, Thomas, \& Nary, 1997). Indeed, the history of counseling has grown out of the concern of early pioneers in the profession for the educational, career, and moral needs of those we serve. Addressing clients' needs is essential to what we are as a profession. However, were it not for efforts to ensure the place of counselors in schools, community agencies, colleges, and private practice, few of us today could legitimately call ourselves "professional counselor," for no such title existed until 28 short years ago (Sweeney \& Sturdevant, 1974). What has been achieved, however, is only part of what is required.

Eriksen (1997) noted that "no one has researched advocacy [for] the counseling field. The only literature in existence is newsletter articles written by advocacy and government 
relations staff or by board members of counseling associations" (p. 2). The result of a lack of attention to professional advocacy is felt most strongly in schools, colleges, agencies, and practices where counselors must compete for jobs and reimbursement for their services along with the members of other mental health professions (Eriksen, 1997; Sweeney, 1995). Too often, credentialed professional counselors are unable to access positions or earn payment commensurate with their level of competence (Chi Sigma Iota, 1999; Engels \& Bradley, 2001; Myers \& Smith, 1999).

In this article, the need for professional advocacy is explored. Issues central to professional advocacy are identified and discussed. The need for a national plan for advocacy is presented and recommendations for practitioner advocacy skills and activities are provided.

\section{THE NEED FOR PROFESSIONAL ADVOCACY}

Brooks and Weikel (1996) traced the history of mental health counseling back to the 1700 s when advocacy for persons with mental illness emerged as a moral issue. The unemployment of youth in the early 1900s motivated Frank Parsons in his work and writings on vocational counseling. Thus, two of the major antecedents of the counseling profession, moral treatment and vocational guidance, are solidly grounded in the needs of clients or client advocacy. The need for counselor advocacy, in contrast, arose as a direct consequence of the evolution of counseling as a profession in the latter half of the twentieth century, most notably with the collaboration of specialty emphases (i.e., school counseling, vocational counseling, counselor education and supervision, and student affairs) to form the American Personnel and Guidance Association (APGA), now the American Counseling Association (ACA), the national professional association for counselors (Richmond \& Remley, 1992).

Glosoff (1996) noted that professional associations provide a vehicle for sharing knowledge; set educational, training, and ethical standards; and "provide advocacy for the advancement and credibility of the professions they represent" (p. 3). Such associations have a responsibility to advocate for the enactment of legislation that reflects the standards and practices of the profession and protects the public from harm. Clearly, a major role of ACA is that of effective advocacy on behalf of professional counselors.

Advocacy efforts for the counseling profession initially focused on school counselors, with state-level credentials being fostered through departments of education. These efforts began in the 1960s after passage of Public Law 85-864, the National Defense Education Act of 1958, provided funds for training institutes and services in the schools for guidance. States created credentialing standards without the benefit of any national guidelines; as a consequence, states varied widely in their criteria. Through the development, adoption, and promotion of national standards, the American School Counselors Association (ASCA), the Association for Counselor Education and Supervision (ACES), and ACA have contributed to greater congruence of state credentials for school counselors (Paisley \& Borders, 1995). Currently, all states require graduate education in guidance and counseling as an entry-level prerequisite for a state credential as a professional school counselor (ACA, 1997). Although school counselor certification remains diverse from state to state, national standards have contributed to greater unanimity at present than existed in previous decades. Currently, school counseling standards in the majority of states and the District of Columbia require attainment of a master's degree in counseling and guidance or a related field, whereas only about half of the states required this two decades ago (ACA, 1997).

It is not surprising that teacher education and training were the original foundation for school counselor credentials (Percy, 1996). The debate over the necessity of classroom teaching experience as a prerequisite for employment as a school counselor continues today, with 13 states requiring both teaching credentials and teaching experience for school counselors (ACA, 1997). More states $(N=17)$ require some type of related school experience but allow for various ways to acquire it including teaching, counseling, counseling practica/internships, human services work, and combinations of similar experiences.

By the 1970s, changes in federal legislation and the evolution of community-based care resulted in increasing numbers of professional counselors seeking employment in community settings (Brooks \& Weikel, 1996). Access to jobs was not automatic. As early as 1977, the Board of Directors of ACA (then APGA) adopted a motion to "give top priority to halting the practice of CETA (Comprehensive Employment Training Act) sponsors and/or managers of hiring unqualified personnel to function as counselors in CETA programs" (APGA, 1977, p. 1). As counselors in community settings continued to face obstacles to achieving employment commensurate with their training, the need for licensure became increasingly evident (Sweeney \& Sturdevant, 1974).

The earliest efforts for professional advocacy outside of school settings came to fruition when the first state board of professional counselor examiners was established in Virginia in 1976 (Bloom, 1996). Today, nearly all states license professional counselors (Bemak \& Espina, 1999). Other major professionalization initiatives include the establishment, in the 1970s, of the Commission on Rehabilitation Counselor Certification (CRCC) and the Council on Rehabilitation Education (CORE) and, in the 1980s, of the National Board for Certified Counselors (NBCC), the Council for Accreditation of Counseling and Related Educational Programs (CACREP), and the American Association for State Counseling Boards (Bloom, 1996; Richmond \& Remley, 1992). As a result of these efforts, more than 73,000 professional counselors are currently credentialed (Bloom, 1996).

The efforts of the various credentialing groups have not been well coordinated (and often not coordinated at all), resulting in the lack of a comprehensive professionalization plan for the counseling profession (Myers, 1995). Although ACA addressed this issue through the development of a professionalization plan in 1991, incorporating the concerns 
of all related counseling organizations (Sweeney, 1995), internal issues have prevented ACA from implementing that plan. Advocacy, a key element targeted for action, remains largely unaddressed due in part to the complexity of counseling as a profession. Several exceptions to this statement should be noted. For example, ACA's government relations staff has successfully advocated for the inclusion of counselors in the Public Health Services Act, making us the fifth mental health profession to achieve core provider status (Goetz \& Barstow, 1999). The NBCC has initiated the Fair Access Coalition on Testing (FACT), a "unified body opposed to attempts by psychologists to restrict professional counselors and other helping professionals from administering and interpreting various testing instruments" (Guerra, 1998, p. 6). NBCC has also initiated a plan to help the few remaining states obtain counselor licensure and has awarded $\$ 9,000$ to one state to begin this effort (Clawson, 1999). Despite these successes, Licensed Professional Counselors have been known not to request third-party payment reimbursement due to the difficulty in receiving positive responses from payers (Geisler, 1995), and, in the early 1990s, attorneys noted that "qualified counselors in private practice are being unfairly discriminated against by health insurance companies" (AMHCA Advocate, 1992, p. 7). More recently, the continued effort of psychologists to prevent counselors from using tests that they have been trained to use creates a pressing need for action (Clawson, 1999).

The establishment of counselor credentials on a national level has had little influence on employment decisions regarding school counselors because state certification through departments of education remains the determining factor in hiring decisions (Schmidt, 1992). Furthermore, reciprocity of counselor licensure across state regulatory boards simply does not exist (Bemak \& Espina, 1999; Emerson, 1996). These examples underscore an important point: If we are to have a coordinated plan for professional advocacy, a number of issues must be considered and addressed.

\section{PROFESSIONAL ADVOCACY: ESSENTIAL ISSUES}

Eriksen (1997) identified several stages of counselor advocacy, beginning with the development of a sense of professional identity. Subsequent stages involve the identification of a problem, assessment of available resources, action, and celebration of success (or evaluation of outcomes and regrouping after losses). Our review of the advocacy literature supports the need for addressing professional identity as a foundation for effective advocacy. In addition, four other areas of concern affect the success of professional advocacy efforts: the public's image of and access to counseling and counselors, interprofessional and intraprofessional collaboration, perceptions of professional pride, and accountability.

\section{Professional Identity}

The identity assumed by a discipline is often reflected in the title, role, and intention of a profession and should result from a unified determination by, of, and for the membership of the discipline (Sweeney, 1995). At present, pro- fessional counselors lack a unified definition of professional counseling and struggles persist to achieve a common focus across the diverse groups within the counseling profession (Myers, 1995; Remley, 1995). In fact, one of the major criticisms of the counseling field regards our inability to clearly define ourselves and distinguish counseling from other mental health professions (Hanna \& Bemak, 1997). The problem of professional identity is complex (Palmo, 1996) and for many years has remained one of the central controversies for all of the mental health professions (Herr \& Cramer, 1987), not just for counseling. What is specific to our field, however, is the diversity and contradictions within our profession that tend to undermine any major sense of mission we may have (Aubrey, 1983).

The difficulty in defining counseling as a profession results, in part, from our broad-based philosophical roots (Sherrard \& Fong, 1991). One complication seems due to our existence within the psychological or mental health disciplines and the consequent areas of overlap with other professional groups, notably psychologists (Pate, 1980). Another problem is the debate over whether counselor educators and counseling psychologists are similar, identical, or different (see Shertzer \& Isaacson, 1977, for an early discussion of these issues) and, relatedly, whether counselors in the community are community counselors (Brooks \& Weikel, 1996) or community psychologists (Goodyear, 1976). The difficulty in achieving a strong sense of professional identity is not limited to counselors working in community settings, however, as reflected in the fact that school counselors have struggled to develop a unique and meaningful professional identity, at least since the 1970s, as have counselors in colleges and other settings (Whitehead, 1974).

One reason for the difficulty in achieving a consensus for a definition of counseling is that we are a specialtybased profession, yet at the same time we have failed to define what is meant by a counseling specialty (Myers, 1995). The question of identity has been related to counselor role (e.g., career development), the setting in which counseling occurs (e.g., schools, community agencies), and the type of clientele served (e.g., rehabilitation, multicultural, aging). Proponents of any one or more of these three identity factors have argued both for a generic profession called "counseling" and for specialty professions (which they may in fact define as the generic profession) called "some-modifierplus-counseling." For example, we have mental health counselors, rehabilitation counselors, school counselors, and substance abuse counselors, all of whom may first call themselves by these names and only secondarily refer to themselves as "professional counselors." To complicate the matter further, discussion within each of these specialties also reflects a struggle for identity.

The lack of a clear, concise, unified definition of professional counseling has had a negative impact on advocacy efforts (Eriksen, 1997). It is more difficult to convince policy makers of the importance of our credentials when those of us within the profession seem unclear about who we are and what we do. The lack of a clear identity can also be particu- 
larly confusing to counselors-in-training. As a consequence of this uncertainty within the profession, it should come as little surprise that the public lacks awareness of the identity and roles of professional counselors.

\section{Public's Image of and Access to Counseling and Counselors}

Consumers are less likely to seek the services of professional counselors if they do not know about our competencies, are uncertain about what we can do for clients, and do not have access to these services through third party or other means; hence, the public's image of and access to counselors are critical. The continuing conflict within our profession about our identity "results in a lack of uniformity and translates into difficulties telling [our] publics who we are and what we do" (Eriksen, 1997, p. 20). While we continue to provide both conflicting and confusing information, "The public expects professional counselors to be properly educated, aware of current knowledge in the field, and committed to practicing in a manner that benefits, and therefore does not harm, the clients they serve. In short, along with the many privileges recognition as a profession brings come a multitude of responsibilities" (Richmond \& Remley, 1992, p. 1). Public image is thus tied to quality assurance, and both are issues involving communication with and accountability to the public.

The barriers to an effective public image for our profession include lack of public knowledge of the field, meager public exposure, conflicted professional loyalties, and modest efforts at self-advocacy (Lent, 1990). Despite longstanding and continued concern about the need to enhance public awareness and support of counseling as well as inclusion of priorities to address this concern in the ACA strategic plan (Nejedlo, Hansen, \& Myers, 1994), the public continues to base its perception of the counseling profession on a combination of image and fact. Unfortunately, this perception may be the profession's weakest link, and, as O'Bryant (1992) noted, our profession can only be "as strong as its weakest link" (p. 1). If counselors are to be successful in advocacy for clients through changes in public policy, the profession must have credibility with the public (Smith, 1992). Regardless of how well the public understands counseling, however, the demand for quality mental health care, and thus for effective standards of practice, is evident (Anderson, 1992).

The existing credentialing efforts of the counseling profession were designed to assure the public of the competence of counseling practitioners, but the lack of public understanding of these credentials contributes to inequities in opportunities for counselors in the marketplace (Bloom, 1996; Sweeney, 1995). For example, because counselors were not included in the Public Health Services Act, consumers did not have the option of using the services of a counselor through Medicaid (Miller, 1996). At the same time that the profession seeks to gain recognition for counselors and counseling, the need to claim the title of "psychologist" in order to receive third party reimbursements weakens our efforts to promote the profession and contributes to internal confusion concerning counselors' roles (Myers \& Smith, 1999). Although the public expects collaboration among service providers, competition and conflict are common and restrict understanding of and access to professional counselors and their services.

\section{Collaboration and Coalitions: Interprofessional and Intraprofessional Collaboration}

Bemak (1998) stressed the need for interdisciplinary collaboration if counselors are to achieve their full potential to effect positive social change. Because societal and individual as well as social problems are complex, multidimensional, multifaceted, and interdisciplinary, partnerships are necessary to achieve positive results and bring about change (Brown \& Lent, 1992). Within any given setting, such as schools, the needs of clients can best be met through the collaborative efforts of all professionals (American School Counselors Association, 1992).

The formation of effective interprofessional alliances rests in no small measure on the perceptions of other mental health providers for the credibility of professional counselors as equals. Such credibility is difficult, even impossible, to achieve in the absence of a unified professional identity that would allow ACA and counseling credentialing groups to act as a group rather than a fragmented organization of groups (Myers, 1995; Sweeney, 1995). Engels and Bradley (2001) documented the difficulties counseling organizations face in forming coalitions and determining key issues for legislative consideration. These difficulties need to be addressed to assure the success of any internal plan for unification or professionalization (Miller, 1996).

Brooks and Gerstein (1990) identified needs for collaboration within the counseling profession through education, research, and improved communication among the helping professions. Such collaboration would result in better services to the public and increased access to employment opportunities for professional counselors. Communication among professionals in different states is also essential in developing advocacy efforts, particularly regarding reciprocity of credentials across states and strategies for collaboration with other professions within each state. Before counselors can work effectively with other mental health providers, a clear definition of the similarities and differences between counseling and other professional groups is needed, along with a sense of security and pride in the definition and accomplishments of our own profession.

\section{Professional Pride}

Counselors often minimize their own work while providing recognition and respect for members of other mental health professions (Eriksen, 1997). It seems that "we have met the enemy, and they are us." A firm foundation of professional pride is essential for effective advocacy and for job satisfaction and such pride is related to credentialing. Counselors 
who are credentialed or who are planning to seek credentialing in the field are more professional and perceive their work to be more important to society than counselors who do not seek credentialing (Tunick \& Tseng, 1981). Similarly, licensure increases counselors' sense of professional competence (Hendrickson, 1983).

Counselors need to recognize that we are "experts"persons who "have knowledge in a trade, art, or science that may not be in ... ordinary daily experience" (Kreishok, 1987, p. 70). "Counseling doesn't happen by accident. We have become counselors through hundreds of hours of classes and study" (Muller, 1992, p. 29). To be silent when others talk about the "counseling" they do promotes "the idea that anyone can 'counsel' and implies that we have no professional identity or pride" (Muller, 1992 , p. 29). Professional pride is directly related to identity and to a common understanding concerning the roles of professional counselors. These roles include advocacy, which in turn requires an understanding of and commitment to accountability.

\section{Accountability}

Regardless of setting, type of clientele, or type of intervention, an essential question for all counselors is whether or not our methods "work" to help persons in need. After a comprehensive review of outcome research in counseling, Sexton, Whiston, Bleuer, and Walz (1997) concluded that "regardless of unique specialty, professional counselors are linked by a common body of professional knowledge" (p. 243). What that body of knowledge shows us is that what we do does indeed "work." Armed with that knowledge, we encourage counselors to engage in social activism or advocacy on behalf of clients. Our knowledge base legitimizes and provides, credibility for our efforts to advocate for needed social change. Thus, a continued emphasis on action-oriented research is imperative for effective advocacy (Allen, 1992; Whiston, 1996). For example, practical applied research designs such as single-subject design research would assist counselors in conducting research that could demonstrate the effectiveness of counselor interventions (Lundervold \& Belwood, 2000).

In addition to outcome research concerning client interventions and treatments, research on the impact of counselor credentialing is needed. Empirical studies of the relationship between rehabilitation counselor training and credentialing have demonstrated that this relationship is overwhelmingly positive: The outcomes of rehabilitation counseling interventions with individuals who have a disability are significantly better for counselors with graduate training in rehabilitation counseling rather than in related degree areas (Szymanski, Linkowski, Leahy, Diamond, \& Thoreson, 1993). Studies conducted in support of rehabilitation counselors should be replicated within the larger profession of counseling; similar findings are likely to result (Remley, 1993).

\section{PROFESSIONAL ADVOCACY: WHAT IS NEEDED?}

The decision to become active in advocacy hinges on identifying a need or problem and having the necessary motivation to take action. One such need or problem is the conflict caused by the discrepancy between counselors' professional skills and their right to fully utilize these skills in the marketplace (Eriksen, 1997). Addressing this problem is the responsibility of individual counselors as well as organizations representing the profession (Glosoff, 1996). In fact, being and becoming active in advocacy has become part of the professional identity of a counselor and remains an imperative if the profession is to survive in a competitive marketplace. Both organizational and practitioner efforts are needed.

To address advocacy we propose seven actions that are interconnected and of equal importance. The need for advocacy is so strong that all of these initiatives must occur simultaneously through a coordinated effort.

1. Counselors must agree on a common identity for our profession.

2. The counseling profession should develop and implement a major national initiative to promote the public image of counseling with a focus on intraprofessional as well as interprofessional activities. The role of counselors as unique mental health providers should be supported and publicized by individual counselors as well as by professional associations and credentialing bodies.

3. Counselors at local, state, national, and international levels should collaborate on issues of concern to the profession and our clients.

4. Counselor preparation and standards for preparation should include advocacy methods and techniques for both social action and advancement of the profession to ensure that counselors view advocacy as integral to their roles and acquire the skills necessary to be effective in advocacy activities.

5. Research on counseling outcomes of credentialed counselors should be implemented and disseminated to demonstrate the effectiveness of our preparation and credentials.

6. Curriculum materials and resources for both professional and client advocacy must be developed for use in training programs.

7. A comprehensive, coordinated plan for advocacy for the counseling profession should be developed and implemented through an intraprofessional coalition comprising all organizations representing professional counselors.

\section{Common Identity}

Professional counselors should take several steps to develop a unified identity for professional counseling. First, further discussion and clarification of what our identity is should 
be addressed. Counselor educators as well as practicing counselors from all of the ACA divisions (e.g., ACES, C-AHEAD) and affiliates (e.g., CACREP, NBCC) must converge and collaboratively flesh out issues associated with counselor identity. Questions such as the following could be addressed through forums at state, regional, and national meetings of counseling associations: How does our identity converge with and diverge from that of other mental health professionals? Where is our niche, and how can this niche be emphasized and marketed to various public sectors? How are our specialty areas defined, and how do they relate to professional counseling in general?

It is also important to discuss these questions and issues regarding identity in various counseling forums, such as conventions and in ACA publications. As many counselors as possible should be involved in ongoing discussions about identity. Because our identity is constantly evolving, discussion of identity issues in ACA publications is essential. Counselors can use information about our identity in communicating with and influencing various public sectors.

Professional identity and professional pride can be promoted by staffing counselor education programs with faculty whose primary professional identity is with counseling. Although the CACREP standards require counseling program coordinators to hold state and/or national counseling credentials and to remain active in state, regional, and national counseling associations (CACREP, 2001), many programs do not follow this staffing protocol and have faculty who are more closely aligned with other professions (e.g., psychology).

Another step that could facilitate the development of a professional identity is to educate counselor trainees and professional counselors about their counseling identity and provide education on the importance of professional advocacy. If leaders in the field of counseling struggle with defining counseling, neophyte counselors will surely struggle as well. Training related to professional identity in counselor education programs along with articles in professional counseling publications (e.g., Counseling Today) or ACAsponsored pamphlets could facilitate an increased understanding of counselor identity and subsequently increase counselor pride. This increased awareness of a global counseling identity could also help in facilitating both a primary loyalty to counseling and a secondary loyalty to the counselors' specialty area (Smith, 2001).

\section{Public Image}

Several strategies can be used to enhance the public image of counselors. First, counselors can establish a positive, high public profile by engaging in public presentations and activities, interacting with various news and radio shows, and writing articles for and sharing information with press outlets. Specific examples of this are school counselors speaking at PTA meetings and community counselors providing public education about mental health services and providers to community populations. Counselors can also speak to various groups concerning their specialty areas. This type of public speaking helps the public both as a preventive intervention and as an educational technique while also promoting the counseling profession. A second public image promotion strategy is to use the term counselor when interacting with the public, thus resisting the tendency to "pass" as members of professions such as psychology or social work. Stating that we engage in counseling rather than therapy is one other way to emphasize the profession of counseling.

One of the most important things we can do to promote the public's access to counseling services is to continue pursuing legislative action that provides reimbursement for counselors' services and that promotes counselors' rights to practice within the limits of their training (e.g., counselors' rights to use assessment instruments). Eriksen (1997) suggested that the most effective means of advocating include personal presentations to government officials, testifying at hearings, litigation, letter writing, and constituent contact. Additional means of legislative advocacy are presenting research results and technical information, informing members of organizations about legislative activities, entering into coalitions with other organizations, talking with the press and media, and helping to draft legislation and with grassroots lobbying efforts.

\section{Interprofessional and Intraprofessional Collaboration}

Strategic planning and advocacy training for members are required for all organizations pursuing an advocacy agenda. A successful national advocacy plan depends on support for agreed-upon legislative priorities to be developed by members and implemented by the staff of counseling associations (i.e., interprofessional collaboration). The ACA Public Policy and Legislation staff is guided by an annual legislative agenda adopted by leaders of the professional association. Rather than allowing these initiatives to fluctuate from year to year with changes in professional leadership, a long-range plan must be developed and followed. One aspect of this plan should be a continued emphasis on the ACA model licensure law (Glosoff, Benshoff, Hosie, \& Maki, 1994) to ensure continued attention to the need for reciprocity among counselor licensure laws. Although a major function of the American Association of State Counseling Boards is to promote interaction and information sharing among states, both with and without counselor licensure, this organization is not empowered to require equivalence of credentials nationally (Emerson, 1996). As a consequence, coalitions of individuals and organizations will be necessary to structure change in this area.

Interprofessional collaboration among mental health providers can help not only in advocating for clients but also in advocating for our profession. Collaboration on legislative issues and other professional issues can decrease professional tensions and help all parties to reach their goals. This collaboration can be achieved by communicating with other professionals and professional organizations. By working to overcome our fears and anxieties 
about competition with others, we will most likely further our objectives.

The most basic way to advocate for counseling is to be a member of professional organizations. Membership dues support counseling, especially regarding important legislative issues that promote the profession.

\section{Counselor Advocacy: Training and Practice}

All counselors have an opportunity, if not a responsibility, to be an advocate for both their clients and themselves. To be an advocate for one and not the other undermines success with either. Many counselors do not have adequate information related to collaborating on professional advocacy issues. Training professional counselors and counselor trainees on how to develop coalitions and grassroots movements when advocating for issues might help to increase counselor efficacy related to collaboration. Ease in communication, in turn, can contribute to more outreach to other counselors. To increase intradisciplinary communication, a directory of contact people in various branches and divisions of ACA would be helpful.

Fortunately, there are ample resources available to help inform and motivate any counselor who understands the need for everyone to participate in the advocacy effort at some level. The ACA Office of Government Relations has excellent, free publications designed to educate and assist individuals willing to invest even minimal time to this effort. For example, the ACA staff has prepared a digest on the need for counseling services, the cost of lack of access to needed services, and the effectiveness of counseling in meeting the needs of those whom we serve (Goetz \& Barstow, 1999). They cite a variety of sources that can be used to support advocacy letters to policy makers and their staff. For example, counselors could use these data to cite the fact that up to 1 in 5 children and young people have psychological problems severe enough to require professional help. However, only $20 \%$ of youth with mental disorders or their families receive help (Hoagwood, 1999). These data-combined with the fact that as of 1998 the current student to counselor ratio in our schools is 513:1 (U.S. Department of Education, 1998), whereas the recommended ratio is 250:1 (Institute of Medicine, 1997) - may help to explain why violence has become such a national issue.

There are also data on other populations across the life span that deal with issues such as substance abuse in the workplace and services to older persons. On its Web site (www.counseling.org), ACA has abundant information concerning various up-to-date legislative issues. All of these sources and materials are designed to help even the busiest counselor have access to information in a convenient format. ACA (1999b) has other excellent publications on effective ways to communicate with legislators, including their e-mail addresses as well as state and national training sessions designed to help members network with others more experienced and prepared to assist on common issues. These opportunities can be accessed through both state and national association public policy committees.

\section{Practitioner Research}

In particular, studies of master's-level counselors' outcome effectiveness compared with that of doctoral-level mental health professionals could lend support for hiring master's-level counselors, particularly in the area of managed care. Although there are various sources of such data already available through NBCC, ACA, and its larger divisions, we lack a compendium of such works as well as a plan for addressing the gaps in our knowledge about counselors' contributions to those whom they serve. Such empirical support for the counseling profession would have tremendous significance for advocacy both on behalf of the clients we serve and on behalf of our profession.

An increased emphasis in counselor training programs on single subject design, qualitative research design, action research, and program evaluation could bolster counselors' confidence in conducting research. These designs are practical for practitioners and seem to be needed given that practitioners generally engage in little research. In addition, ACA publications such as Counseling Today could publish regular columns related to practitioners' use of single subject research. Counseling journals might also consider publishing more single case research studies as opposed to group comparison research studies. This would model the use of single subject design research and encourage counselors' efficacy in this area.

\section{Curriculum Materials and Resources for Advocacy}

To foster training in advocacy issues, counselors may use various materials already available from ACA and its divisions, such as the advocacy packet developed by the American School Counselors Association. ACA government relations staff will provide copies of materials for training purposes. In addition, Eriksen's (1997) book on counselor advocacy is a helpful resource. The Chi Sigma Iota Web site (http://www.csi-net.org) includes a summary of the national advocacy conferences and strategies for advocacy. Counselor educators may find a need to develop additional materials to include in core courses.

\section{A Comprehensive Plan}

The good news is we in the counseling profession have a precedent for unified action through consensus as reflected in the 1991 Professionalization Plan (ACA, 1991). The various organizations represented in the development of that plan are the same ones now active in current advocacy efforts. A number of milestones were achieved more quickly, in part, because of the dialogue, agreement, and resolve made possible by the face-to-face meetings associated with the plan and its implementation. In addition, there is evidence that new initiatives are underway both for clients and for the profession. For example, there is now a featured section of Counseling Today with articles addressing client issues (ACA, 1999a). A new organization, Counselors for Social Justice, was recently established within ACA with the mission of advocacy for client issues. 
Despite these initiatives, all branches and divisions of ACA must continue to work together to achieve professional advocacy initiatives. Collaboration and unification as evidenced by intraprofessional meetings and communications are necessary to facilitate a coordinated advocacy plan.

\section{CONCLUSION}

Of necessity, advocacy is a two-pronged effort that includes advocacy for client well-being and for the profession. Both are necessary and within the scope of training and practice of professional counselors. Counselors can be more effective advocates for clients when our profession is recognized by other mental health professions as well as legislators and policy makers. To accomplish this recognition, a comprehensive national plan for advocacy, prepared and implemented through a coalition of counselors and counseling organizations, is needed and is, in fact, a professional imperative.

\section{REFERENCES}

Allen, J. (1992). Action-oriented research: Promoting school counselor advocacy. ERIC Digest. Greensboro, NC: ERIC/CAPS.

American Counseling Association. (1991). Professionalization plan. Alexandria, VA: Author.

American Counseling Association. (1997). Guide to state laws and regulations on professional school counseling. Alexandria, VA: Author.

American Counseling Association. (1999a). Advocacy: A voice for our clients and communities. Counseling Today, pp. 28-31.

American Counseling Association. (1999b). Effective advocacy and communications with legislators. Alexandria, VA: Author.

American Personnel and Guidance Association. (1977, July). Board of directors' action from the July, 1977 meeting. Alexandria, VA: Author.

American School Counselors Association. (1992). A position statement: The professional school counselor and the use of non-school credentialed personnel in the counseling program. Alexandria, VA: Author.

AMHCA Advocate. (1992, May). Discrimination suit committee forming in Pennsylvania, p. 7.

Anderson, D. (1992). A case for standards of practice in counseling. Journal of Counseling \& Development, 71, 22-26.

Aubrey, R. (1983). The odyssey of counseling and images of the future. The Personnel and Guidance Journal, 62, 78-82

Bemak, F. (1998). Interdisciplinary collaboration for social change: Redefining the counseling profession. In C. Lee \& G. Walz (Eds.), Social action: A mandate for counselors (pp. 279-292). Alexandria, VA: American Counseling Association.

Bemak, F., \& Espina, M. R. (1999, Winter). Professional counseling licensure: Going from state to state. Spectrum, p. 4.

Bloom, J. W. (1996). Credentialing professional counselors for the 21 st Century. In J. W. Bloom (Ed.), Credentialing professional counselors for the 21st Century (pp. 1-2). Greensboro, NC: ERIC/CASS.

Brooks, D. K., \& Gerstein, L. H. (1990). Interprofessional collaboration: Or shooting yourself in the foot only feels good when you stop. Journal of Counseling \& Development, 68, 477-484.

Brooks, D. K., \& Weikel, W. J. (1996). Mental health counseling: The first twenty years. In W. J. Weikel \& A. J. Palmo (Eds.), Foundations of mental health counseling (pp. 5-29). Springfield, IL: Thomas.

Brown, S. D., \& Lent, R. W. (Eds.). (1992). Handbook of counseling psychology. New York: Wiley.

Chi Sigma Iota. (1999). Counselor advocacy leadership conferences report. Greensboro, NC: Author.

Clawson, T. (1999, March). National Board for Certified Counselors. Counseling Today, p. 24.
Council for Accreditation of Counseling and Related Educational Programs. (2001). The 2001 standards. Alexandria, VA: Author.

Emerson, P. (1996). Will other state boards accept my credential? Reciprocity revisited. In J. W. Bloom (Ed.), Credentialing professional counselors for the 21st Century (pp. 7-8). Greensboro, NC: ERIC/Cass.

Engels, D. W., \& Bradley, L. J. (2001). Advocacy for the counseling profession. In D. C. Locke, J. E. Myers, \& E. L. Herr (Eds.), The handbook of counseling (pp. 569-579). Thousand Oaks, CA: Sage.

Eriksen, K. (1997). Making an impact: $A$ handbook on counselor advocacy. Washington DC: Taylor \& Francis/Accelerated Development.

Geisler, J. S. (1995). The impact of the passage of the counselor licensure law. Journal of Mental Health Counseling, 17, 188-198.

Glosoff, H. L. (1996). Counselor licensure laws: The role of the American Counseling Association. In J. W. Bloom (Ed.), Credentialing professional counselors for the 21st Century (pp. 3-4). Greensboro, NC: ERIC/CASS

Glosoff, H. L., Benshoff, J. M., Hosie, T. W., \& Maki, D. (1994). The 1994 ACA model legislation for licensed professional counselors. Journal of Counseling \& Development, 74, 209-220.

Goetz, B., \& Barstow, S. (1999). The effectiveness of professional counseling services. Alexandria, VA: American Counseling Association.

Goodyear, R. K. (1976). Counselors as community psychologists. The Personnel and Guidance Joumal, 54, 513-515.

Guerra, T. (1998, March). FACT holds sixth meeting. Counseling Today, p. 6 .

Hanna, F. J., \& Bemak, F. (1997). The quest for identity in the counseling profession. Counselor Education and Supervision, 36, 196-204.

Hendrickson, L. (1983). The licensure of mental health counselors. Greensboro, NC: Author. (ERIC Document \#246319)

Herr, E. L., \& Cramer, S. H. (1987). Controversies in the mental health professions. Muncie, IN: Accelerated Development.

Hoagwood, K. (1999, March). Summary sheet-Major research findings on child and adolescent mental health. Washington, DC: National Institute of Mental Health

Institute of Medicine. (1997). Schools and health. Washington, DC: National Academy Press.

Kreishok, T. S. (1987). Psychologists and counselors in the legal system: A dialogue with Theodore Blau. Joumal of Counseling and Development, 66, 69-72.

Lee, C. C. (1998). Counselors as agents of social change. In C. C. Lee \& G. R. Walz (Eds.), Social action: A mandate for counselors (pp. 3-14). Alexandria, VA: American Counseling Association.

Lent, R. W. (1990). Further reflections on the public image of counseling psychology. Counseling Psychologist, 18, 324-332.

Lewis, J. A., \& Arnold, M. S. (1998). From multiculturalism to social action. In C. Lee \& G. Walz (Eds.), Social action: A mandate for counselors (pp. 51-66). Alexandria, VA: American Counseling Association.

Lundervold, D. A., \& Belwood, M. F. (2000). The best kept secret in counseling: Single-case $(N=1)$ experimental designs. Journal of Counseling \& Development, 78, 92-102.

McClure, B. A., \& Russo, T. R. (1996). The politics of counseling: Looking back and forward. Counseling and Values, 40, 162-174.

McWhirter, E. H. (1997). Empowerment, social activism, and counseling. Counseling and Human Development, 29, 1-14.

Miller, M. J. (1996, October). Advocacy: What works? Paper presented at the Association for Counselor Education and Supervision National Conference, Portland, Oregon.

Muller, L. E. (1992, March). Who does counseling? Guidepost, p. 29.

Myers, J. E. (1995). Specialties in counseling: Rich heritage or force for fragmentation? Journal of Counseling \& Development, 74, 115-116.

Myers, J. E., \& Smith, H. (1999). Third party payments: Status for counselors. Greensboro, NC: ERIC/CASS.

Nejedlo, B., Hansen, S., \& Myers, J. E. (1994). A strategic plan for AACD's future: The precursors of ACA. Journal of Counseling \& Development, 72, 276-281.

O'Bryant, B. J. (1992). Marketing yourself as a professional counselor. ERIC Digest. Greensboro, NC: ERIC/CAPS.

Paisley, P. O., \& Borders, L. D. (1995). School counseling: An evolving specialty. Journal of Counseling \& Development, 74, 150-153. 
Palmo, A. J. (1996). Professional identity of the mental health counselor. In W. J. Weiker \& A. J. Palmo (Eds.), Foundations of mental health counseling (pp. 51-72). Springfield, IL: Thomas.

Pate, R. H. (1980). The counselor in a psychological society. The Personnel and Guidance Journal, 58, 521-524.

Percy, R. L. (1996). Teaching experience for school counselors revisited: An alternative certification model. In J. W. Bloom (Ed.), Credentialing professional counselors for the 21st Century (pp. 25-26). Greensboro, NC: ERIC/CASS.

Perry, J. L., \& Locke, D. C. (1985). Career development of Black men: Implications for school guidance services. Journal of Multicultural Counseling and Development, 13, 106-111.

Remley, T. P. (1993). Rehabilitation counseling: A scholarly model for the generic profession of counseling. Rehabilitation Counseling Bulletin, 37, 182-186.

Remley, T. P. (1995). A proposed alternative to licensing of specialties in counseling. Journal of Counseling \& Development, 74, 126-129.

Richmond, L. G., \& Remley, T. P. (1992). Counselor membership in ACA. ERIC Digest. Greensboro, NC: ERIC/CAPS.

Schmidt, J. J. (1992, October). Counselor credentialing and school counselor employability in North Carolina. Paper presented at the Annual Convention of the Association for Counselor Education and Supervision, San Antonio, TX.

Sexton, T. L., Whiston, S. C., Bleuer, J. C., \& Walz, G. R. (1997). Integrating outcome research in counseling practice. Alexandria, VA: American Counseling Association.

Sherrard, P.A., \& Fong, M. L. (1991). Mental health counselor training: Which model shall prevail? Joumal of Mental Health Counseling, 13, 204-210.

Shertzer, B., \& Isaacson, L. (1977). A counselor educator views counseling psychologists: Problems in professional identity. Counseling Psychologist, 7, 33-35.

Smith, H. (1992, Spring). Rationale for counselor involvement in public policy. The Dakota Counselor, p. 2.

Smith, H. (2001). Professional Identity for counselors. In D. C. Locke, J. E. Myers, \& E. L. Herr (Eds.), The handbook of counseling (pp. 569 579). Thousand Oaks, CA: Sage.

Sweeney, T. J. (1995). Accreditation, credentialing, professionalization: The role of specialties. Journal of Counseling \& Development, 74, 117-125.

Sweeney, T. J., \& Sturdevant, A. D. (1974). Licensure in the helping professions: The anatomy of an issue. The Personnel and Guidance Journal, 52, 575-580.

Szymanski, E. M., Linkowski, D. C., Leahy, M. J., Diamond, E. E., \& Thoreson, R. W. (1993). Validation of rehabilitation counseling accreditation and certification knowledge areas: Methodology and initial results. Rehabilitation Counseling Bulletin, 37, 109-122.

Tunick, R. H., \& Tseng, M. S. (1981). Professional identity, job satisfaction, and rehabilitation counselor certification. Rehabilitation Counseling Bulletin, 25, 74-79.

U.S. Department of Education. (1998). Digest of education statistics 1998. Washington, DC: Author.

Vash, C. (1987). Fighting another's battles: When is it helpful? Professional? Ethical? Journal of Applied Rehabilitation Counseling, 18, 15-16.

Whiston, S. (1996). Accountability through action research: Research methods for practitioners. Journal of Counseling \& Development, 74, 616-623.

White, G., Thomas, R., \& Nary, D. (1997). An empirical analysis of the effects of a self-administered advocacy letter training program. Rehabilitation Counseling Bulletin, 41, 74-87.

Whitehead, E. (1974). The counselor as a social force: Identifying counselor role and functions in community the college. Greensboro, NC: Author. (ERIC Document \#105917)
- NEW SERIES-

\section{Multicultural Foundations of} Psychology and Counseling

Series Editors: Allen E. Ivey and Derald Wing sue

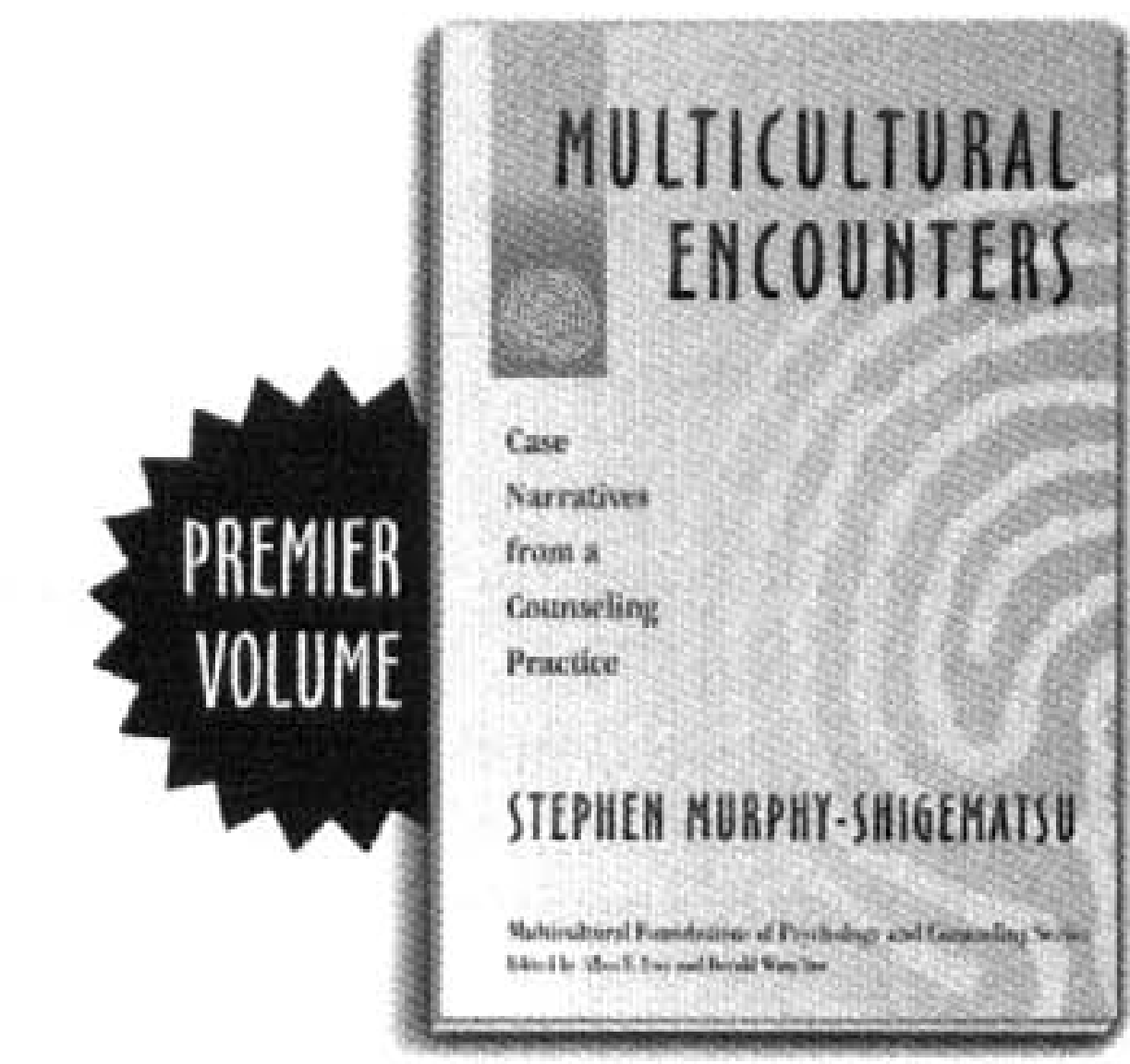

Multicultural Encounters

Case Narratives from a Counseling Practice

\section{Stephen Murphy-Shigematsu \\ Professor, Tokyo University and \\ Visiting Scholar, Stanford University}

"Recommended with the greatest enthusiasm."

-Chester M. Pierce, MD, Harvard University

This volume uses fascinating therapeutic encounters to help clinicians understand and respond to the needs of their increasingly diverse clientele. Emphasizing the importance of balancing general cultural awareness with a consciousness of openness and curiosity, Murphy-Shigematsu urges clinicians to look beyond their assumptions and stereotypes to learn the client's cultures through eliciting key narratives. Keeping the client and therapist center stage, the author shows the complex ways in which their cultural self-narratives interact.

2002/144 pp./Pb, \$21.95/4258-9/Cl, \$48/4259-7

$$
\text { -ALSO OF INTEREST- }
$$

\section{Narratives in Action}

\section{A Strategy for Research and Analysis}

Stanton E. F. Wortham

Foreword by Kenneth J. Gergen

This volume provides: a systematic account of how narrative self-construction works... a dialogic account of self-construction that focuses on the social, cultural, and relational contexts of storytelling .... and step-bystep guidance on how to uncover and document meaningful patterns in transcribed narrative data.

2001/208 pp./Pb, \$27.95/4075-6/Cl, \$66/4076-4 Counseling and Development Series

TO ORDER: 800.575.6566

Teachers College Press

Teachers College Columbia University www.tcpress.com 